\title{
Pengembangan Media Permainan Uno Stacko Dalam Bimbingan Karir Tentang Pemahaman Eksplorasi Karir
}

\author{
Nur Aini Endah Agustia \\ Universitas Ahmad Dahlan, Yogyakarta, Indonesia \\ nur1600001276@webmail.uad.ac.id \\ Ulfa Danni Rosada \\ Universitas Ahmad Dahlan, Yogyakarta, Indonesia \\ ulfa.rosada@bk.uad.ac.id
}

\begin{abstract}
Abstrak
Penelitian ini bertujuan untuk mengetahui kondisi objektif pemahaman eksplorasi karir, untuk mengetahui hasil uji validasi ahli materi dan hasil uji ahli media terhadap pengembangan media permainan uno stacko dalam bimbingan karir tentang pemahaman eksplorasi karir pada siswa kelas IX di SMP Negeri 1 Rajagaluh. Penelitian ini menggunakan jenis penelitian dan pengembangan atau yang dikenal dengan R\&D (Research and Development) dengan menggunakan model Brog and Gall hingga tahap ke-5. Teknik pengumpulan data berupa lembar penilaian. Analisis data menggunakan analisis kualitatif dan kuantitatif. Berdasarkan hasil penilaian ahli materi pengebangan media permainan uno stacko dalam bimbingan karir tentang pemahaman eksplorasi karir memperoleh nilai 82 dengan kriteria "Sangat Baik", hasil penilaian ahli media memperoleh nilai 75 dengan kriteria "Baik". Dengan demikian berdasarkan penilaian kedua ahli di atas, media permainan uno stacko dalam bimbingan karir tentang pemahaman eksplorasi karir pada siswa kelas IX di SMP Negeri 1 Rajagaluh dinyatakan layak untuk digunakan.
\end{abstract}

Kata kunci: Eksplorasi Karir, Uno Stacko, Bimbingan Karir. 


\title{
Abstract
}

\begin{abstract}
Uno Stacko Game Media Development In Career Guidance About Understanding Career Exploration. This study aims to determine the objective conditions of career exploration understanding, to find out the results of the material expert validation test and the results of the media expert test on the development of the Uno Stacko game media in career guidance about understanding career exploration in class IX students at SMP Negeri 1 Rajagaluh. This research uses a type of research and development or known as $R \& D$ (Research and Development) using the Brog and Gall model until the 5th stage. The data collection technique is in the form of an assessment sheet. Data analysis used qualitative and quantitative analysis. Based on the results of the expert's assessment of the material development material for the uno stacko game media in career guidance on understanding career exploration, the score was 82 with the criteria of "Very Good", the results of the assessment of media experts obtained a score of 75 with the criteria of "Good". Thus, based on the assessment of the two experts above, the uno stacko game media in career guidance on understanding career exploration for class IX students at SMP Negeri 1 Rajagaluh is declared feasible to use.
\end{abstract}

Keywords: Career Exploration, Uno Stacko, Career Guidance.

\section{A. Pendahuluan}

Menurut Undang-Undang No. 20 Tahun 2003 (Depdiknas, 2003) tentang Sistem Pendidikan Nasional dalam pasal 1 disebutkan bahwa pendidikan merupakan usaha sadar dan terencana untuk mewujudkan suasana belajar dan proses pembelajaran agar peserta didik secara aktif mengembangkan potensi dirinya untuk memiliki kekuatan spiritual keagamaan, pengendalian diri, kepribadian, kecerdasan, akhlak mulia, serta keterampilan yang diperlukan dirinya, masyarakat, bangsa dan negara. Pendidikan yang berkaitan dengan pendidikan formal yaitu sekolah. Sekolah sebagai lembaga pendidikan merupakan suatu wadah yang didalamnya terjadi suatu proses kegiatan belajar mengajar yang dilakukan oleh guru sebagai tenaga pendidik dan peserta didik/siswa. Sedangkan salah satu bagian integral dari pendidikan adalah adanya layanan bimbingan dan konseling bagi peserta didik. Tujuan bimbingan dan konseling adalah untuk mengembangkan potensi pada individu seoptimal mungkin, sesuai dengan 
kemampuan agar bisa menyesuaikan diri dengan lingkungannya, baik lingkungan sekolah, keluarga maupun lingkungan masyarakat (Bastomi, 2020). Menurut Yusuf \& Nurihsan dalam Bastomi (2019) Proses Bimbingan dan Konseling di sekolah dapat berhasil apabila mempunyai tujuan yang jelas yang akan dicapainya. Bimbingan dan konseling bertujuan untuk membantu peserta didik agar dapat mencapai tujuan-tujuan perkembangannya yang meliputi aspek pribadi-sosial belajar (akademik) dan karir. Sedangkan tujuan bimbingan dan konseling Islam menurut Mubarok dalam Bastomi (2017) Secara singkat dapat dirumuskan sebagai berikut : (1) Tujuan umum Konseling Islam untuk membantu kon seli agar dia memiliki pengetahuan tentang posisi dirinya dan memiliki keberanian mengambil keputusan, untuk melakukan suatu perbuatan yang dipandang baik, benar dan bermanfaat, untuk kehidupannya di dunia dan untuk kepentingan akhiratnya. (2) Tujuan khusus bimbingan konseling Islam adalah: (a) Untuk membantu konseli agar tidak menghadapi masalah. (b) Untuk membantu konseli mengatasi masalah yang sedang dihadapinya. (c) Untuk membantu konseli memelihara dan mengembangkan situasi dan kondisi yang baik atau yang telah baik agar tetap baik, sehingga tidak akan menjadi sumber masalah bagi dirinya dan orang lain. Guna mencapai tujuan bimbingan konseling sesuai yang diharapkan tentunya proses manajemen bimbingan dan konseling harus berjalan dengan sangat baik.

Siswa pada jenjang sekolah menengah pertama (SMP) termasuk dalam usia remaja. Masa remaja rata-rata berada di usia 12-18 tahun, masa remaja juga disebut sebagai masa peralihan perkembangan antara masa kanak-kanak dan masa dewasa. Pada masa ini tak heran jika remaja mengalami kebingungan mengenai perkembangan dan pertumbuhan fisik yang lebih cepat. Seperti yang terjadi pada remaja wanita, yaitu mulai mengalami fase menstruasi dan pada remaja pria mengalami mimpi basah. Pada masa ini remaja berada pada tahap eksplorasi karir. Eksplorasi karir merupakan suatu aktivitas pencarian informasi mengenai karakteristik diri yang berkaitan dengan kelemahan dan kekuatan atau bakat dan minat individu untuk mencapai tujuan karir yang sesuai dengan bakat 
dan minat siswa. Hal ini sesuai dengan pendapat Suherman (Priyatno, 2016) berpendapat bahwa eksplorasi karir merupakan suatu keinginan individu untuk melakukan pencarian informasi terhadap beberapa sumber informasi karir. Pemahaman mengenai eksplorasi karir sangat diperlukan siswa agar dapat mengambil keputusan dan merencanakan karir dengan tepat dan mampu mengaplikasikan sesuai dengan minat dan bakat yang dimiliki siswa.

Berdasarkan apa yang telah dijelaskan di atas, peneliti melakukan studi pendahuluan di SMP Negeri 1 Rajagaluh tentang eksplorasi karir. Berdasarkan studi pendahuluan yang dilakukan oleh peneliti melalui kegiatan wawancara, guru bimbingan dan konseling menjelaskan bahwa masih terdapat siswa yang masih belum memahami eksplorasi karir, juga rendahnya pengetahuan dan pemahaman siswa terkait pentingnya eksplorasi karir karena kurangnya informasi terkait eksplorasi karir dari berbagai sumber. Pelaksanaan layanan bimbingan dan konseling yang spesifik membahas mengenai eksplorasi karir belum dilakukan. Guru BK juga belum memiliki inovasi terkait penggunaan media permainan uno stacko dalam layanan bimbingan dan konseling. Salah satu upaya dalam mengatasi permasalahan pemahaman eksplorasi karir pada siswa berdasarkan hasil riset diatas yaitu dengan memberikan layanan bimbingan karir. Hibana S.Rahman (Azizah, 2016) berpendapat bahwa bimbingan karir merupakan layanan yang diberikan kepada siswa untuk merencanakan dan mengembangkan masa depan berkaitan dengan dunia pendidikan maupun dunia karir.

Seseorang yang memberikan layanan bimbingan dan konseling di sekolah yaitu guru BK. Guru BK memiliki peran yang sangat penting dalam memberikan pemahaman terkait eksplorasi karir pada siswa. Seiring berkembangnya zaman guru BK dituntut untuk memberikan layanan bimbingan konseling yang kreatif, inovatif serta efisien sehingga siswa tidak merasa bosan. Oleh karena itu seorang guru BK harus memiliki daya kreativitas dalam menyampaikan materi yaitu dengan menggunakan media dalam pemberian layanan bimbingan karir. Media yang digunakan haruslah media yang menarik dan inovatif seperti media permainan uno stacko tentang eksplorasi karir. Menurut Pavilion (Angelina \& 
Hamdun, 2019) bahwa uno stacko merupakan balok berwarna warni yang terbuat dari potongan kayu atau plastik mainan yang disusun seperti bentuk menara ataupun bentuk yang lain dan dimainkan oleh dua atau lebih dari tujuh orang pemain.

Berdasarkan pemaparan diatas dapat ditarik kesimpulan bahwa dalam memberikan pemahaman tentang eksplorasi karir maka peneliti membutuhkan suatu pembaharuan media. Media permainan uno stacko menjadi fokus yang menarik dan penting untuk dikembangkan. Dengan adanya media tersebut diharapkan dapat menjadi kegiatan layanan bimbingan dan konseling yang efektif dan efisien serta dapat meningkatkan keaktifan siswa. Dengan demikian peneliti merasa penting untuk meneliti mengenai Pengembangan Media Permainan Uno Stacko Dalam Bimbingan Karir Tentang Pemahaman Eksplorasi Karir Pada Siswa Kelas IX di SMP Negeri 1 Rajagaluh. Berdasarkan kajian fenomena tersebut, maka diperoleh beberapa tujuan dalam penelitian ini antara lain (1) Untuk mengetahui kondisi objektif pemahaman eksplorasi karir siswa kelas IX di SMP Negeri 1 Rajagaluh; (2) Untuk mengetahui hasil uji validasi ahli materi terhadap pengembangan media permainan uno stacko dalam bimbingan karir tentang pemahaman eksplorasi karir pada siswa kelas IX di SMP Negeri 1 Rajagaluh; (3) Untuk mengetahui hasil uji validasi ahli media terhadap pengembangan media permainan uno stacko dalam bimbingan karir tentang pemahaman eksplorasi karir pada siswa kelas IX di SMP Negeri 1 Rajagaluh.

\section{B. Metode}

Penelitian ini menggunakan jenis penelitian dan pengembangan atau yang dikenal dengan $\mathrm{R} \& \mathrm{D}$ (Research and Development) dengan menggunakan model Brog and Gall. Langkah-lagkah penelitian dan pengembangan yaitu: (1) potensi dan masalah, (2) pengumpulan data, (3) desain produk, (4) validasi desain, (5) revisi desain, (6) uji coba produk, (7) revisi produk, (8) uji coba pemakaian, (9) revisi produk, (10) produksi masal. Namun dalam pengembangan media permainan ini peneliti mengikuti metode pengembangan Borg and Gall yang telah disederhanakan menjadi lima tahap (Tim Puslitjaknov, 2018), yakni: 1) potensi 
dan masalah, 2) pengumpulan data, 3) desain produk, 4) validasi desain, 5) revisi desain. Hal ini dikarenakan keterbatasan peneliti dalam segi waktu dan kendala keadaan pandemi yang tidak memungkinkan untuk melakukan uji coba langsung ke sekolah. Subyek uji coba yang digunakan dalam penelitian dan pengembangan ini adalah ahli materi dan ahli media. Teknik pengumpulan data berupa lembar penilaian. Pada produk ini melakukan 2 uji kelayakan yaitu uji validasi ahli materi, dan ahli media. Analisis data menggunakan analisis kualitatif dan kuantitatif.

\section{Pembahasan}

\section{Eksplorasi Karir}

Eksplorasi karir telah dikonseptualisasikan dalam teori dan penelitian yang mencakup kegiatan-kegiatan yang diarahkan untuk meningkatkan pengetahuan seseorang tentang diri sendiri dan lingkungan eksternal yang melibatkan individu untuk mendorong kemajuan dalam pengembangan karir. Seorang individu yang terlibat dalam eksplorasi karir mengumpulkan informasi tentang diri mereka sendiri dan lingkungan mereka dengan tujuan untuk maju dalam pengembangan karir mereka. Keputusan remaja tentang jalur karir mana yang harus dipilih sering kali dipandu oleh jenis kegiatan pencarian informasi ini.

Dalam disertasinya, Teori Kognitif Sosial dan Eksplorasi Karir Siswa Sekolah Menengah, Sickinger menyarankan eksplorasi karir paling baik dipahami jika dilihat melalui berbagai teori pengembangan karir. Teori pembelajaran sosial menjelaskannya sebagai "pencarian informasi ... atau sebagai perilaku pemecahan masalah karir." Teori keputusan karir menggambarkannya sebagai "identifikasi dan evaluasi pilihan dan perilaku pencarian informasi." Terakhir, ahli teori perkembangan melihatnya hanya sebagai bagian dari tahap remaja.

Penulis Taveira dan Moreno lebih lanjut mendefinisikan aktivitas eksplorasi karir dengan menunjukkan, "Singkatnya, hanya adanya perilaku pencarian informasi atau penilaian diri tidak dengan sendirinya menjamin bahwa kita berada dalam proses eksplorasi karir. Sebaliknya, eksplorasi karir membutuhkan perilaku berorientasi pada tujuan karir. Artinya selain menggali minat dan bakatnya 
sendiri, pemuda dalam proses eksplorasi karir juga harus mengidentifikasi tujuan dan mengembangkan langkah-langkah untuk mencapai tujuan tersebut.

Penulis terkenal lainnya, Blustein, menunjukkan pandangan pembelajaran sosial memberi tahu kita bahwa kegiatan eksplorasi tidak secara intrinsik bermanfaat dan oleh karena itu faktor lingkungan harus membangkitkan, mempertahankan, dan memperkuat perilaku eksplorasi ini. Dia mengutip karya Lazarick, Fishbein dan Howard yang menemukan bahwa siswa yang diminta untuk mengeksplorasi lebih berhasil dalam mengeksplorasi diri dan lingkungannya (melalui buku kerja mandiri) daripada kelompok pembanding yang diminta untuk tidak mengeksplorasi. Dia juga merekomendasikan intervensi harus diarahkan untuk meningkatkan keterampilan klien dalam eksplorasi lingkungan dan memberi mereka sarana belajar bagaimana memperoleh informasi pekerjaan.

a. Pengertian Eksplorasi Karir

Eksplorasi karir merupakan suatu aktivitas pencarian informasi mengenai karakteristik diri yang berkaitan dengan kelemahan dan kekuatan atau bakat dan minat individu untuk mencapai tujuan karir yang sesuai dengan bakat dan minat siswa. Eksplorasi karir merupakan kemampuan dan segala aktivitas individu dalam mencari, mendapatkan, dan mengelola informasi karir sehingga membantu individu dalam memilih dan mempersiapkan diri untuk karirnya (Priyatno, 2016).

b. Tujuan Eksplorasi Karir

Tujuan dari eksplorasi karir yaitu untuk mengembangkan pengetahuan individu tentang informasi karir dan untuk menggali potensi diri dan lingkungan karirnya. Hal tersebut selaras dengan pendapat Studer (Anwar, 2017) tujuan eksplorasi karir adalah mengembangkan pemahaman secara luas terhadap karir yang tersedia, variasi karakteristik kerja, relevan si mata pelajaran dengan dunia kerja serta evaluasi diri.

c. Indikator-Indikator Eksplorasi Karir

Menurut Suherman (2011) terdapat indikator-indikator eksplorasi karir, antara lain: (1) Berusaha menggali dan mencari informasi karir dari 
berbagai sumber, yakni Informasi karir merupakan suatu faktor yang penting dan diperlukan individu untuk memperoleh pemahaman karir. Hal ini individu berusaha mencari informasi terkait karir dari berbagai sumber misalnya guru bimbingan dan konseling, orang tua, orang sukses, teman, dan sebagainya. (2) Memiliki pengetahuan tentang potensi diri yakni Hal ini individu dituntut untuk bisa memahami potensi diri yang ada pada individu berdasarkan dengan bakat, minat, serta kemampuan diri sehingga individu dapat mengembangkan potensi tersebut. (3) Memiliki cukup banyak informasi karir yakni Memiliki banyak informasi karir dapat membantu individu dalam merencanakan karir yang akan ditempuh kedepannya. Sehingga dalam hal ini individu hendaknya memiliki wawasan yang luas terkait karir yang ingin dituju dengan mencari informasi dari berbagai sumber sebelum terjun ke dunia kerja.

\section{d. Faktor-Faktor yang Mempengaruhi Eksplorasi Karir}

Priyatno (2016) berpendapat bahwa faktor yang dapat mempengaruhi eksplorasi karier terbagi menjadi dua yaitu faktor internal dan faktor eksternal. (1) Faktor internal yang berpengaruh terhadap eksplorasi karir siswa adalah prestasi akademik. Prestasi akademik yang tinggi menjadi salah satu faktor siswa lebih mudah melakukan eksplorasi karir karena didukung oleh kemampuan dalam mencerna dan mengolah informasi karir, baik yang diperoleh dari dalam diri maupun dari lingkungan tempat individu tinggal. (2) Faktor eksternal dalam eksplorasi karir diantaranya adalah tuntutan keluarga untuk berubah, faktor lainnya berkaitan dengan kehidupan karir, dan tuntutan sosial budaya tempat individu berada. Faktor eksternal lainnya yaitu orang tua yang merupakan faktor penting dari eksplorasi karir seseorang. Orang tua berperan penting dalam membantu individu serta mampu memberi dukungan sosial dan sumber daya psikologis serta orang tua dapat menumbuhkan efek positif pada pengalaman pelaku eksplorasi individu.

e. Tahap-Tahap Eksplorasi Karir 
Menurut Suherman (2011) menyatakan level eksplorasi karir meliputi tiga sub tahapan, yaitu sub tahap tentative, sub tahap transisi dan sub tahap mencoba. Adapun penjelasannya sebagai berikut: (1) Sub tahap tentatif (usia antara 15-17 tahun). Tahap ini dikarakterisasikan dengan mulai dipertimbangkannya aspek-aspek kebutuhan, minat, kapasitas, nilai-nilai dan kesempatan secara menyeluruh; (2) Sub tahap transisi (usia antara 18-21 tahun). Tahap ini dikarakterisasikan dengan menonjolnya pertimbangan yang lebih realistis untuk memasuki dunia kerja atau latihan professional serta berusaha mengimplementasikan konsep dirinya; (3) Sub tahap mencoba (trial) dengan sedikit komitmen (usia antara 22-24 tahun). Dikarakterisasikan dengan mulai ditemukannya lahan atau lapangan pekerjaan yang dipandang cocok, serta mencobanya sebagai suatu yang sangat potensial.

\section{Layanan Bimbingan Karir}

a. Pengertian Bimbingan Karir

Layanan bimbingan karir diperlukan sebagai bagian yang tak terpisahkan dari bimbingan dan konseling yang dapat membantu siswa mengatasi dan menuntaskan permasalahan-permasalahan karir. Berikut beberapa pendapat ahli yang menjelaskan tentang bimbingan karir. Menurut Winkel (Lestari, 2017) menyatakan bahwa:

Bimbingan karir adalah bimbingan dalam mempersiapkan diri menghadapi dunia pekerjaan, dalam memilih lapangan pekerjaan/profesi tertentu serta membekali diri supaya siap memangku jabatan itu, dan dalam menyesuaikan diri dengan berbagai tuntutan dari lapangan pekerjaan yang telah dimasuki.

b. Tujuan Bimbingan Karir

Tujuan bimbingan karir yang dikemukakan oleh Surya (Lestari, 2017) adalah membantu individu untuk memperoleh kompetensi yang diperlukan agar dapat menemukan perjalanan hidupnya dan mengembangkan karir yang dipilihnya secara optimal. 
c. Fungsi Bimbingan Karir

Dalam pelaksanaan bimbingan karir mempunyai fungsi yang baik agar tujuan dalam kegiatan tersebut dapat tercapai. Menurut Sukardi (Ahmad, 2019) pemberian bimbingan karir kepada siswa memiliki fungsi yaitu sebagai berikut: (1) Fungsi preventif adalah pemberian informasi yang dapat membantu peserta didik mengambil suatu keputusan dalam memasuki dunia kerja atau karir, ini berarti bimbingan karir berfungsi mencegah tindakan yang keliru dalam mengambil suatu keputusan. (2) Fungsi distributif adalah pemberian informasi kepada siswa yang dapat memperluas wawasan dalam pekerjaan dan jabatan sehingga peserta didik memiliki alternatif pekerjaan yang dapat di sesuaikan dengan potensi diri. (3) Fungsi rujukan adalah pemberian informasi kepada peserta didik di sekolah yang dapat membantu peserta didik untuk menelaah, bertanya, dan menggali lebih dalam segala yang ingin diketahuinya.

d. Prinsip-Prinsip Bimbingan Karir

Dalam pemberian layanan bimbingan karir terdapat beberapa prinsip dasar yang dipandang sebagai pondasi atau landasan, bagi pelaksanaan layanan bimbingan karier. Menurut Sukardi (Ahmad, 2019) mengungkapkan 10 prinsip-prinsip pelaksanaan bimbingan karier, akan di jelaskan yaitu sebagai berikut: (1) Seluruh siswa hendaknya mendapat kesempatan yang sama untuk mengembangkan dirinya dalam pencapaian karirnya secara tepat. (2) Setiap siswa hendaknya memahami bahwa karir itu adalah sebagai suatu jalan hidup, dan pendidikan adalah sebagai persiapan untuk hidup. (3) Siswa hendaknya dibantu dalam mengembangkan pemahaman yang cukup memadai terhadap diri sendiri dan kaitannya dengan perkembangan sosial pribadi dan perencanaan pendidikan karir. (4) Siswa perlu diberikan pemahaman tentang dimana dan mengapa mereka berada dalam suatu alur pendidikannya. (5) Siswa secara keseluruhan hendaknya dibantu untuk memperoleh pemahaman tentang hubungan antara pendidikan dan karirnya. (6) Pada setiap tahap 
program pendidikan siswa hendaknya memiliki pengalaman yang berorientasi pada karir secara berarti dan realistik. (7) Siswa hendaknya memilih kesempatan untuk menguji konsep, berbagai peranan dan keterampilannya guna mengembangkan nilai-nilai dan norma-norma yang memiliki aplikasi bagi karir di masa depannya. (8) Program bimbingan karir hendaknya memiliki tujuan untuk merangsang perkembangan pendidikan siswa. (9)Program bimbingan karir di sekolah hendaknya di integrasikan secara fungsional dengan program pendidikan pada umumnya dan program bimbingan dan konseling pada khususnya; (10)Program bimbingan karir di sekolah hendaknya berpusat di kelas, dengan koordinasi oleh pembimbing, disertai partisipasi orang tua dan kontribusi masyarakat.

\section{Media Permainan Uno Stacko}

\section{a. Pengertian Permainan Uno Stacko}

Menurut Wikipedia Uno stacko adalah Permainan menyusun balokbalok membentuk menara dengan mengambi balok dari bagian bawah atau tengah menara dan meletakkannya di puncak menara secara bergantian tanpa boleh merobohkan menara atau menjatuhkan balok lain. Sedangkan menurut Angelina \& Hamdun (2019) Media uno stacko merupakan media permainan edukatif berbentuk susunan balok warna-warni yang menarik dan dapat meningkatkan kemampuan kognitif anak.

b. Manfaat Permainan Uno Stacko

Beberapa manfaat bermain Uno Stacko yang dikemukakan oleh Fathani (Roziqin, 2017) antara lain :

1) Meningkatkan keterampilan kognitif

Kognitif keterampilan kognitif berkaitan denga kemampuan untuk belajar dan memecahkan masalah. Dengan bermain uno stacko para pemain akan mencoba memecahkan masalah yaitu menyusun balok secara teratur dan rapi.

2) Meningkatkan keterampilan motorik 
Motorik halus keterampilan motorik halus berkaitan dengan kemampuan menggunakan otot-otot kecilnya khususnya tangan dan jari-jari tangan. Supaya balok dapat tersusun membentuk bangunan maka bagian-bagian balok harus disusun secara hati-hati.

3) Meningkatkan keterampilan sosial

Keterampilan sosial berkaitan dengan kemampuan berinteraksi dengan orang lain. Uno stacko dapat dimainkan secara perorangan. Namun uno stacko dapat pula dimainkan secara kelompok. Permainan yang dilakukan oleh secara kelompok akan meningkatkan interaksi social antara pemainnya. Dalam kelompok, anggota akan saling menghargai, saling membantu dan berdiskusi satu sama lain.

4) Melatih kesabaran

Bermain uno stacko membutuhkan ketekunan, kesabaran dan memerlukan waktu untuk berpikir dalam menyelesaikan tantangan.

5) Meningkatkan konsentrasi

Bermain uno stacko membutuhkan konsentrasi ketika akan mengambil dan memindahkan balok uno stacko yang telah diambil diletakkan diatas, karena jika tidak hati-hati akan menyebabkan tumpukan uno stacko tersebut roboh dan permainan selesai.

\section{Media Permainan Uno Stacko Dalam Bimbingan Karir Tentang Pemahaman Eksplorasi Karir}

Hasil penelitian Pengembangan media permainan uno stacko dalam bimbingan karir tentang pemahaman eksplorasi karir ini menunjukkan bahwasannya permainan uno stacko dalam bimbingan karir tentang pemahaman eksplorasi karir ini layak digunakan pada siswa. Hasil dari penelitian ini diukur dengan menggunakan lembar penilaian validasi ahli, yaitu validasi ahli materi dan validasi ahli media. Dari kedua uji validasi tersebut dilakukan dua tahap penilaian. Berikut ini masing-masing nilai uji validasi ahli materi dan media, yaitu: 1) Uji validasi ahli materi mendapatkan nilai 82 yang termasuk kategori sangat baik, dan 2) Uji validasi ahli media mendapatkan nilai 75 kategori baik, 
sehingga dapat diketahui nilai akhir memperoleh rata-rata 78,75 yang termasuk kategori baik.

Titik kunci pembahasan dalam penelitian ini didasarkan pada Kongruensi antara pertanyaan penelitian, hasil dan teori. Ketiga aspek tersebut kemudian didialogkan secara strategis untuk memperoleh posisi hasil penelitian dengan kajian teori yang telah ada. Pertanyaan penelitian dalam penelitian ini dijawab melalui hasil penelitian mulai fase awal yakni need assessment hingga penilaian dan proses validasi dari para ahli.

Skor yang masuk dalam kategori "baik" menunjukkan indikator bahwa aspek aspek dalam pengembangan produk telah berjalan sesuai dengan kebutuhan dan perencanaan. Hasil tersebut juga sesuai dengan harapan peneliti tentang pengembangan produk yang lebih baik. Walaupun belum sampai pada akhir tahapan yakni diseminasi produk, namun dalam praktiknya, produk telah selesai dan siap untuk diluncurkan kepada siswa dan guru BK.

\section{Simpulan}

Berdasarkan hasil penelitian dan pengembangan, maka dapat disimpulkan media permainan uno stacko dalam bimbingan karir tentang pemahaman eksplorasi karir pada siswa kelas IX di SMPN 1 Rajagalu sebagai berikut: Kondisi objektif pemahaman eksplorasi karir siswa kelas IX di SMP Negeri 1 Rajagaluh masih tergolong rendah, hal ini disampaikan sendiri oleh guru bimbingan dan konseling bahwa masih terdapat siswa yang masih belum memahami eksplorasi karir, juga rendahnya pengetahuan dan pemahaman siswa terkait pentingnya eksplorasi karir karena kurangnya informasi terkait eksplorasi karir dari berbagai sumber.

Hasil dari penelitian ini diukur dengan menggunakan lembar penilaian validasi ahli, yaitu validasi ahli materi dan validasi ahli media. Dari kedua uji validasi tersebut dilakukan dua tahap penilaian. Berikut ini masing-masing nilai uji validasi ahli materi dan media, yaitu: 1) Uji validasi ahli materi mendapatkan nilai 82 yang termasuk kategori sangat baik, dan 2) Uji validasi 
ahli media mendapatkan nilai 75 kategori baik, sehingga dapat diketahui nilai akhir memperoleh rata-rata 78,75 yang termasuk kategori baik.

Berdasarkan penjelasan poin-poin di atas, tujuan dari penelitian ini dapat terjawab. Selain hal tersebut, maka dapat disimpulkan pengambangan media permainan uno stacko dalam bimbingan karir tentang pemahaman eksplorasi karir pada siswa kelas IX di SMPN 1 Rajagaluh dapat dikatakan layak untuk digunakan.

Adapun saran dari hasil peneltian yaitu pengembangan media permainan uno stacko tentang pemahaman eksplorasi karir ini dapat dijadikan sebagai media layanan untuk membantu guru bimbingan dan konseling dalam menyampaikan materi agar siswa tidak merasa bosan. Media permainan uno stacko ini dapat digunakan dalam layanan bimbingan karir. Dengan adanya pengembangan media ini, diarapkan dapat memberikan inovasi baru bagi guru dalam melaksanakan layanan bimbingan dan konseling, hal tersebut dapat terwujudkan tujuan bimbingan dan konseling. 


\section{DAFTAR PUSTAKA}

Ahmad, R. R. N. (2019). Layanan Bimbingan Karir Dalam Upaya Meningkatkan Kemandirian Siswa Dalam Memilih Karir Di Ma Salafiyah Wonoyoso Bumirejo Kebumen (Perspektif Bimbingan Konseling Islam). In Skripsi Fakultas Dakwah Dan Komunikasi Universitas Islam Negeri Walisongo Semarang (Vol. 8, Issue 5).

Angelina, M., \& Hamdun, D. (2019). Pengembangan Media Pembelajar an Ta'bīr Berbasis Permainan Uno Stacko pada Siswa MA Ibnul Qoyyim Putra Yogyakarta. Al Mahāra: Jurnal Pendidikan Bahasa Arab, 5(2), 209-232. https://doi.org/10.14421/almahara.2019.052.04

Anwar, M. K. (2017). Model Eksplorasi Karir Sebagai Upaya Persiapan Karir Siswa Dalam Menghadapi Asean Global. Jurnal Konseling GUSJIGANG, 3(1), 53-57.

Azizah, A. N. (2016). Pelaksanaan Layanan Bimbingan Karir Di Smp Negeri SeKecamatan Career Guidance' S Implementation in Junior High Schools Sub District Depok. 12, 603-609.

Bastomi, H. (2017). Menuju Bimbingan Konseling Islami. KONSELING EDUKASI: Journal Of Guidance And Counseling, 1 No. 1. https://doi.org/10.21043/konseling.v1i1.4434

Bastomi, H. (2019). Konseling Cyber: Sebuah Model Konseling Pada Konteks Masyarakat Berbasis Online. Konseling Edukasi: Journal of Guidance and Counselling, 3, No. 1.

Bastomi, H. (2020). Pemetaan Masalah Belajar Siswa SMK Negeri 3 Yogyakarta Dan Penyelesaiannya (Tinjauan Srata Kelas). KONSELING EDUKASI: Journal of Guidance And Counseling, 4 No. 1.

Depdiknas. (2003). Undang-Undang Republik Indonesia No 20 Tentang Sistem Pendidikan Nasional. Jakarta: Direktorat Pendidikan Menengah Umum, 6. http://stpi-binainsanmulia.ac.id/wpcontent/uploads/2013/04/Lamp_2_UU20-2003-Sisdiknas.doc

Lestari, I. (2017). Dipublikasikan oleh: Program Studi Bimbingan dan Konseling FKIP Universitas Muria Kudus MENINGKATKAN KEMATANGAN KARIR REMAJA MELALUI BIMBINGAN KARIR BERBASIS LIFE SKILLS. Jurnal Konseling GUSJGANG, 3(1), 2503-281. http://dx.doi.org/10.24176/jkg.v3i1.859

Priyatno, T. (2016). Upaya Meningkatkan Pemahaman Eksplorasi Karir Melalui Layanan Bimbingan Kelompok dengan Teknik Diskusi Kelompok. PSIKOPEDAGOGIA Jurnal Bimbingan Dan Konseling, 5(1), 49. https://doi.org/10.12928/psikopedagogia.v5i1.4489

Roziqin, M. (2017). Pengaruh Permainan Uno Stacko Terhadap Peningkatan Fungsi 
Pengembangan Media Permainan Uno Stacko.....

Kognitif Lansia Di Griya Usila Santo Yosef Surabaya. Skripsi Fakultas Keperawatan Universitas Airlangga (Vol. 13, Issue 3). 